\title{
Population Settlement Changes Due to Migration Impacts in Mongolia
}

\author{
Amangul Shugatai ${ }^{1, *}$, Otgonkhuu Tsedevish ${ }^{2}$, Enkh-Amgalan Sandag ${ }^{2}$ \\ ${ }^{I}$ Institute of International Affairs, Mongolian Academy of Sciences, Ulaanbaatar, Mongolia \\ ${ }^{2}$ Institute of Geography and Geoecology, Mongolian Academy of Sciences, Ulaanbaatar, Mongolia \\ "Corresponding author. Email: amangulsh@mas.ac.mn
}

\begin{abstract}
In 1990, Mongolia experienced a volatile change in the social, political, and economic aspects of its society. In particular, inequality, poverty, and unemployment increased exponentially and the differences in development between urban and rural areas increased sharply. During this period population migration intensified, particularly in rural to urban migration. Mongolia shifted from a socialist to a market economy, and social-economic attitudes also has shifted towards "settled life" as resettlements intensified. Many nomadic herders have migrated to their respective province centers, as well as to other mining and industrial centers, in order to benefit from developing infrastructure in these settlements. This process has negatively affected goals of sustainable population settlement, and created an over-concentration of the population in province centers and the country's largest cities. The strongest effect of this migration flow comes in sustaining rural settlements, and has a significant impact on population concentration in larger urban areas. In this way, there is a practical need for an in-depth study of natural and socio-economic factors affecting Mongolia's population migration processes. This study highlights the results of intensified population settlement and urbanization in Mongolia. These processes have created major challenges for policy makers. Therefore, this study investigates how socio-economic factors in Mongolia, affect the settlement and resettlement of Mongolia's population. We conclude with an assessment of population settlement in future trends.
\end{abstract}

Keywords: Migration, Population Settlement Changes, Socio-economic Factors, Urbanization, Mongolia

\section{INTRODUCTION}

Mongolia is a landlocked country located in Northeast Asia. It is located between Russia to the north and China to the southeast and west. Mongolia's territory is 1564100 square kilometers. Several distinctive natural zones characterize the country: the western and northern parts are high mountain and forested region, the eastern part is grassy steppe, and the southern part comprises the famous Gobi Desert. The population of Mongolia is estimated at 3.35 million people in 2020 [1].

Administratively, the country is divided into 21 aimags or provinces (first level administrative units) and the capital city of Ulaanbaatar. Aimags are divided into soums (second-level administrative units); and the capital city is divided into districts. Soums are sub-divided into baghs. With a population density of 1.72 persons per square kilometre, Mongolia is the lowest densely populated country in the world.

Since 1990, Mongolia has shifted from a socialist to a market economy, in a process that also shifted local attitudes "settled life". The result is a negative impact on sustainable population settlement, including an over-concentration of population in aimag centers and large cities. The strongest effect of this migration flow comes in the loss of population from rural settlements, and has a significant impact on population concentration in larger urban areas. Therefore, there is a practical need for a comprehensive study of natural and socio-economic factors affecting the population migration processes.

This research aims to analyze recent migration to Mongolia's central region in comparison with other 
stems of migration, and to provide a comprehensive framework for proper coordination of migration. The goal is improve Mongolia's settlement system given its current clustering of a large population instead of dispersing people over a vast territory. Therefore, this research will focus on analyzing the current situation of population migration into central region of Mongolia, evaluating how to reduce negative consequences and improve, the sustainability of population settlement.

The impacts of migration on population settlement, urbanization, social services, mining, extractive industries, transportation, and livestock breeding locations will be used to identify population patterns, forms, and spatial changes. Current social movements address the issues of population, with suggestions for more rational choices of population settlement. The study developed a comprehensive survey method and methodology on the impact of migration changes of Mongolia, using socioeconomic geographic analysis, statistical data for the GIS mapping and field surveys from urban and rural areas.

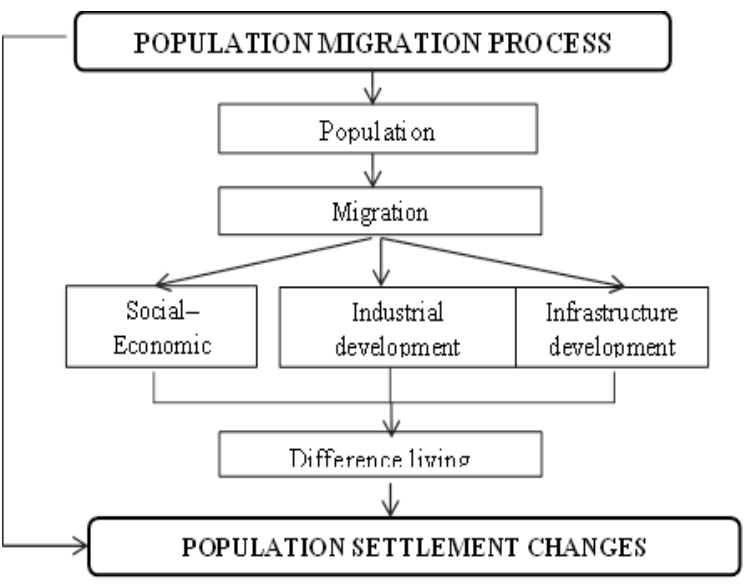

Figure 1. Research design

\section{RESEARCH DATA AND METHOD}

Within the framework of the study, the socioeconomic and demographic characteristics under investigation include age, literacy and education, material and living status, labour force status, employment activities, status, occupation and industry, and the reason for unemployment. Shifts in population are affected by migration rather than just net population growth, and therefore, this study will use the information to estimate the settlement of rural population as a result of migration, as well as migration intensity, direction, and consequences.
Official statistics, collected based on migration statistics (1990-2020) [2], the population and Housing Census 2000, 2010 and 2020 preliminary results (by aimags), domestic and international research reports, demography issues scientific articles, and field survey material including household-based data from soums and interviews collected by randomly selecting households using a sociological questionnaire.

The questionnaire design will include: social and demographic characteristics of household members (age, gender, marital status and ethnicity), geographical and spatial characteristics and economic, educational, and housing issues.

The study used socio-economic and geographic research methods to create GIS maps.

\section{THE IMPACTS OF MIGRATION IN MONGOLIA}

Since 1990 Mongolia's urbanization has been expanding due to the intensification of migration and the influx of migrants to major settlements such as aimag centers and the capital city. As a result, new migrant districts are emerging in some districts. Many newly established khoroos (the administrative unit of Ulaanbaatar city) have inadequate infrastructure and basic social services, making it difficult for districts in the city to access education and health care.

In rural Mongolia, shortages of job opportunities have also been influencing migration flows. The migration to the central region of Ulaanbaatar city from the Western regions are characterized by the highest rates of unemployment, at 18.5 percent in 2016 respective to other regions [1]. Migration from the Western region, however, was probably also due to push factors which need to be investigated closely. It should also be noted that most internal migrants went to Ulaanbaatar. The pattern of "stepping -stone" migration from the West and East to the Central region and then to the capital city should also be studied in the future.

According to official statistical data [1], 35.2 percent of the total population are living with low income. In particular, the incidence of poverty in soum centers and among the rural population is higher than in urban and aimag centers. Specially, those who live in rural areas have the highest likelihood to be in poverty, driving their migration to urban areas. 
The official data also showed [1] that the labour force participation rate was $58.8 \%$ and the employment to population ratio was $54.6 \%$ in 2020 . The composite measure of labour underutilization was $12.4 \%$, and the unemployment rate was $7.0 \%$ in 2020 [1] . The combined rate of unemployment and the potential labour force was $12.0 \%$, and the combined rate of time-related underemployment and unemployment was $7.4 \%$ in 2020 [1].

This lead to migration flows into urban areas and province centers. As a result, the biggest cities have expanded. This makes cities and provinces centers larger, creating new districts and small administrations. This creates challenges for the new district's infrastructure, and big problems for that district's population. As a result of this migration process, it becomes difficult to extend social services to cover the whole population, ensuring all can study in school, be treated in hospitals and so on. Some statistics [1] show the most migrants flows came from the remote aimags to the Central region. From these, people are migrating to the capital city of Ulaanbaatar, while the number of in-migrants from the Eastern province is relatively low [3]. As a result of this migration process, many migrants settle in urban areas and sub-divisions, creating overpopulation and overconcentration of people, urban loads, disruption in land use, livestock clusters, pasture degradation, environmental pollution, inadequate use of natural resources, and productionterritorial disorders. This process has a substantial effect on socio-economic factors, including regional economic development capacity [4]. Further, the biggest cities face problems such as socio-economic and environmental over-population, pasture degradation from livestock living in the center of the city, and environmental pollutions, affecting everyday quality of life. On the other hand, the population of Mongolia's administrative units has been more variable, with rural areas remote from the center of the province being abandoned [5;6]. For example, 50 percent of all soums at present have only 3000 people living in the soum center and rural areas [1].

Migration is a major factor in the changes in the territorial population's size, and administrative composition. Over the last 30 years, internal and external migration have intensified, and the population structure of aimags, the capital city, and the regions have undergone significant changes, having a strong impact on social and economic development.

The official statistical data shows [1], the Mongolia's urbanization rate has increased rapidly due to rural-urban migration, reaching 54.0 percent in $2000,67.9$ percent in 2010, and 67.2 percent in 2020 . These increases have been due to the increased migration from the countryside to major industrial cities, and the capital city of Ulaanbaatar (Figure 2). As thousands of people move from rural to urban areas, the urban population is growing year by year in addition to normal growth.

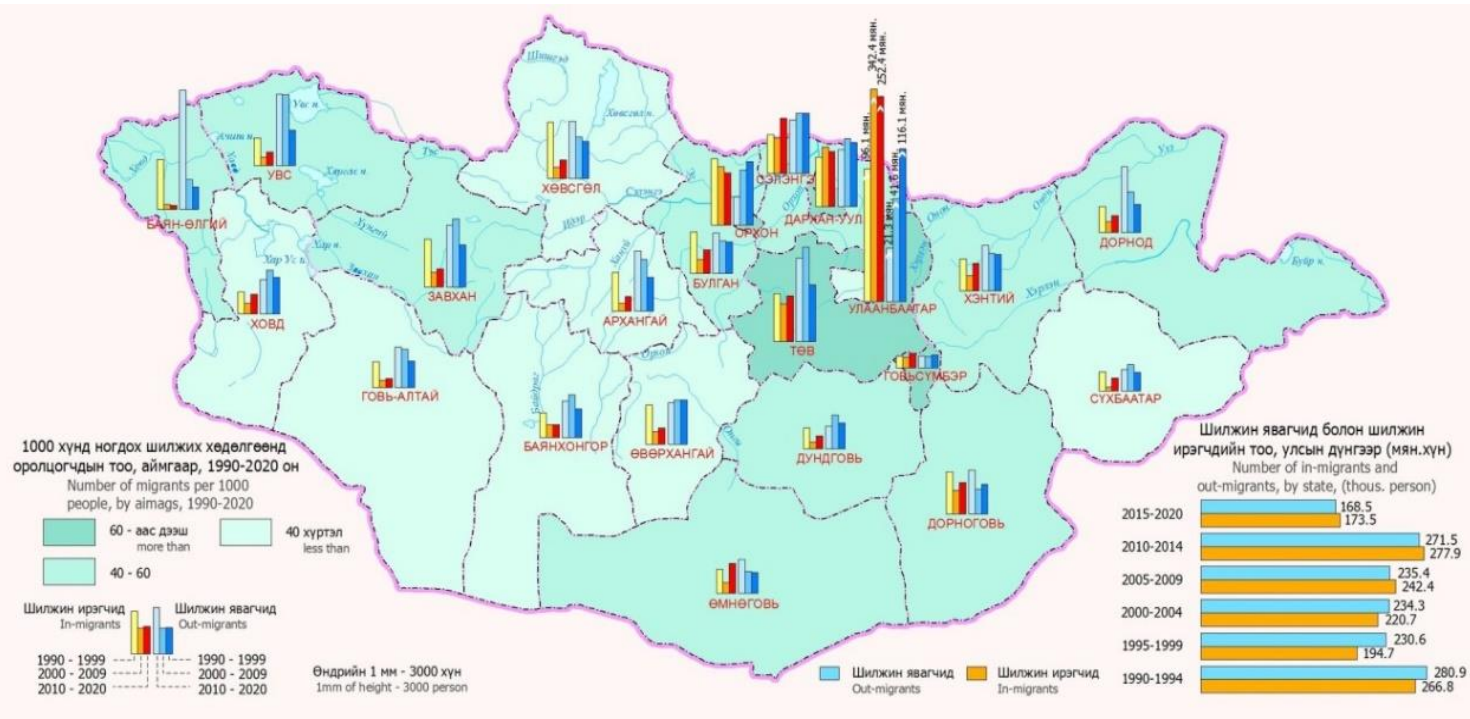

Figure 2. Population Migration 1990-2020

Data source: National Statistical Year Book, 1990-2020, www.1212mn 


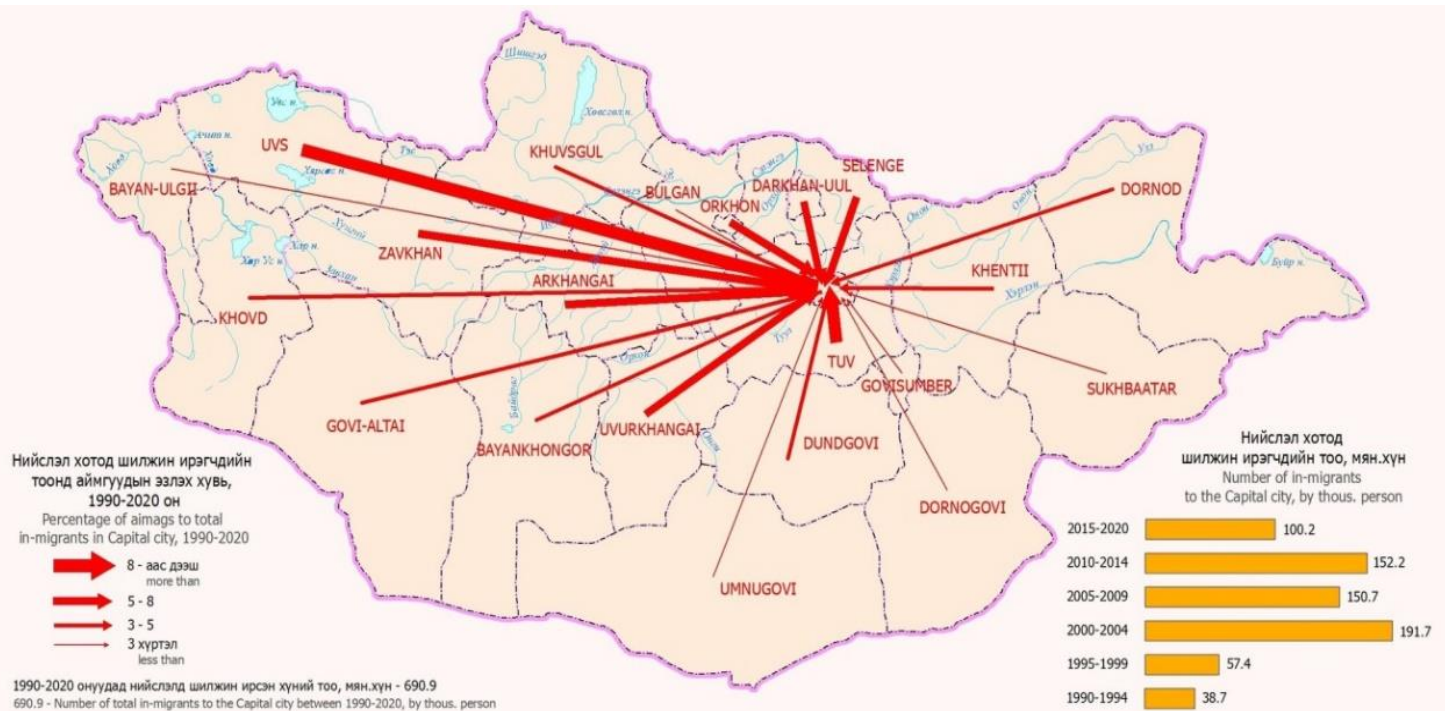

Figure 3. In-Migrants 1990-2000 (by aimag)

Data source: National Statistical Year Book, 1990-2020, www.1212mn

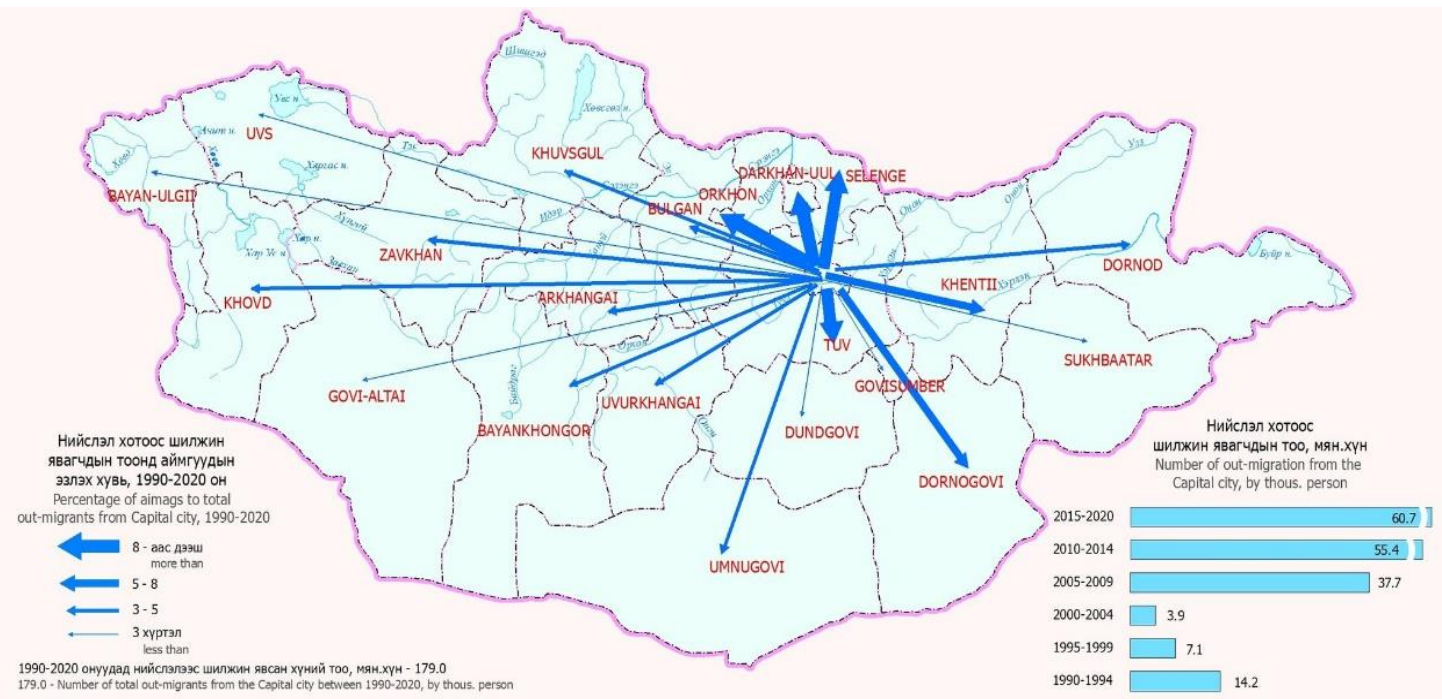

Figure 4. Out-Migrants 1990-2000 (by aimag)

Data source: National Statistical Year Book, 1990-2020, www.1212mn

Field surveys show that most migrants move in order to find a job, seeking better living condition and unemployment. This suggests that rural herders are moving away from low-income agricultural sector work, and toward move to more secure urban areas with jobs in industry, infrastructure, and mining.

The field survey shows that 55.9 percent of respondents moved away from their home region in order to find a job. 28 percent moved to visit relatives living in urban areas (Table 1). In addition, 6.9 percent moved to buy household goods at a lower price, and 4.6 percent to stay close to large cities, along roads, and to follow their livestock to pastureland. One highlight of this study is that no households reported migrating primarily for quality of medical care and access to social welfare services and better education.

Most migrants are in young age groups in Mongolia. In the five years prior to the 2010 housing census, most of migrants were aged 20-24, with the remainder aged 15-19 and 25-29. Compared to those moving to other regions, many young people are moving to urban areas, especially Ulaanbaatar city. For example, in the last five years, almost 48 percent of migrants to Ulaanbaatar were between 16 and 34 years old [7]. 
Table 1. Factors affecting migration participants

\begin{tabular}{|c|l|c|c|}
\hline \multirow{2}{*}{ Trade and market } & \multicolumn{1}{c|}{ Reason } & $\begin{array}{c}\text { Number of } \\
\text { Households }\end{array}$ & $\begin{array}{c}\text { Percent } \\
\%\end{array}$ \\
\hline \multirow{3}{*}{ Infrastructure } & Buy daily goods at low prices & 3 & 6.9 \\
\cline { 2 - 4 } & It is close located to big cities and along the road & 2 & 4.6 \\
\cline { 2 - 4 } & Mobile phone network optional & 0 & 0 \\
\cline { 2 - 4 } & It has a guaranteed energy source & 0 & 0 \\
\hline \multirow{5}{*}{ Employment } & Find a job (look for another source of income) & 24 & 0 \\
\hline \multirow{3}{*}{ Environment service } & Give your child a better education & 0 & 0 \\
\cline { 2 - 4 } & Receive good quality medical care & 0 & 28.0 \\
\cline { 2 - 4 } & Access to social welfare services & 12 & 4.6 \\
\cline { 2 - 4 } & Be closer to your relatives & 2 & 0 \\
\hline & Better pastures and grasslands and need for & 0 & 100 \\
\cline { 2 - 4 } & livestock condition & 43 & \\
\hline
\end{tabular}

Data source: Field research survey, 2017-2018

Table 2. Indigenous and in-migrant households (Education level of the household husband)

\begin{tabular}{|l|c|c|c|c|c|}
\hline $\begin{array}{c}\text { Education level of the } \\
\text { household husband) }\end{array}$ & $\begin{array}{c}\text { Number of households } \\
\text { surveyed }\end{array}$ & Indigenous & $\begin{array}{c}\text { Percent } \\
\%\end{array}$ & In-Migrants & $\begin{array}{c}\text { Percent } \\
\%\end{array}$ \\
\hline Uneducated & 3 & 3 & 1.9 & 0 & 0.0 \\
\hline Primary & 28 & 22 & 14.0 & 6 & 14.0 \\
\hline Lower secondary & 54 & 41 & 26.1 & 13 & 30.2 \\
\hline Upper secondary & 66 & 55 & 35.0 & 11 & 25.6 \\
\hline Technical \& specialized skill & 15 & 14 & 8.9 & 1 & 2.3 \\
\hline Tertiary Total & 34 & 22 & 14.0 & 12 & 27.9 \\
\hline \multicolumn{1}{|c|}{200} & 157 & 100.0 & 43 & 100.0 \\
\hline
\end{tabular}

Data source: Field research survey, 2017-2018

\section{POPULATION SETTLEMENT CHANGES OF MONGOLIA}

Population settlement is a geographical and spatial concept that is expressed in many ways, such as the status of the city and village where people live, employment, housing, housing conditions, and access to social services [9]. Simply put, it can be understood as a way of life in which people live [8]. One of the biggest issues is proper resettlement of the population and how to appropriately manage resettlement. In this regard, it is necessary to analyze the current situation of the population settlement and scientifically model the population according to Mongolian social development trends.

Mongolia's total population increased in urban ares, while the share of the rural population has decreased between 1990 and 2020. For instance, in the Khangai region 32.0 percent lived in urban areas, and the remaining 68.0 percent lived in rural areas in 1990. By 2000, 29.4 percent of the population lived in urban areas and 70.6 percent in rural areas. And by
2020, 39.5 percent of those in the Khangai region lived in urban areas, with 60.5 percent living in the rural areas.

During the transition to a market economy in 1990, Mongolia's urban population increased from 1.2 million to 1.7 million in $2000,2.1$ million in 2010, and 2.3 million in 2020. The urban and rural population has been growing for the past 30 years. The rural population in the Khangai region is relatively larger than the rural population in the Central and Eastern regions due to the more favorable climate and the large number of livestock and agricultural settlements in the Khangai region.

The central region's population was $48.6 \%$ lived in urban areas and 51.4 percent resides in rural areas in 1990 . By 2020, 60.3 percent lived in urban areas and 36.7 percent resides in the countryside

However, compared to the Khangai region, the urban population in the Central and Eastern regions is higher, in this instance due to the predominance of minerals, mining, light and heavy industries. 


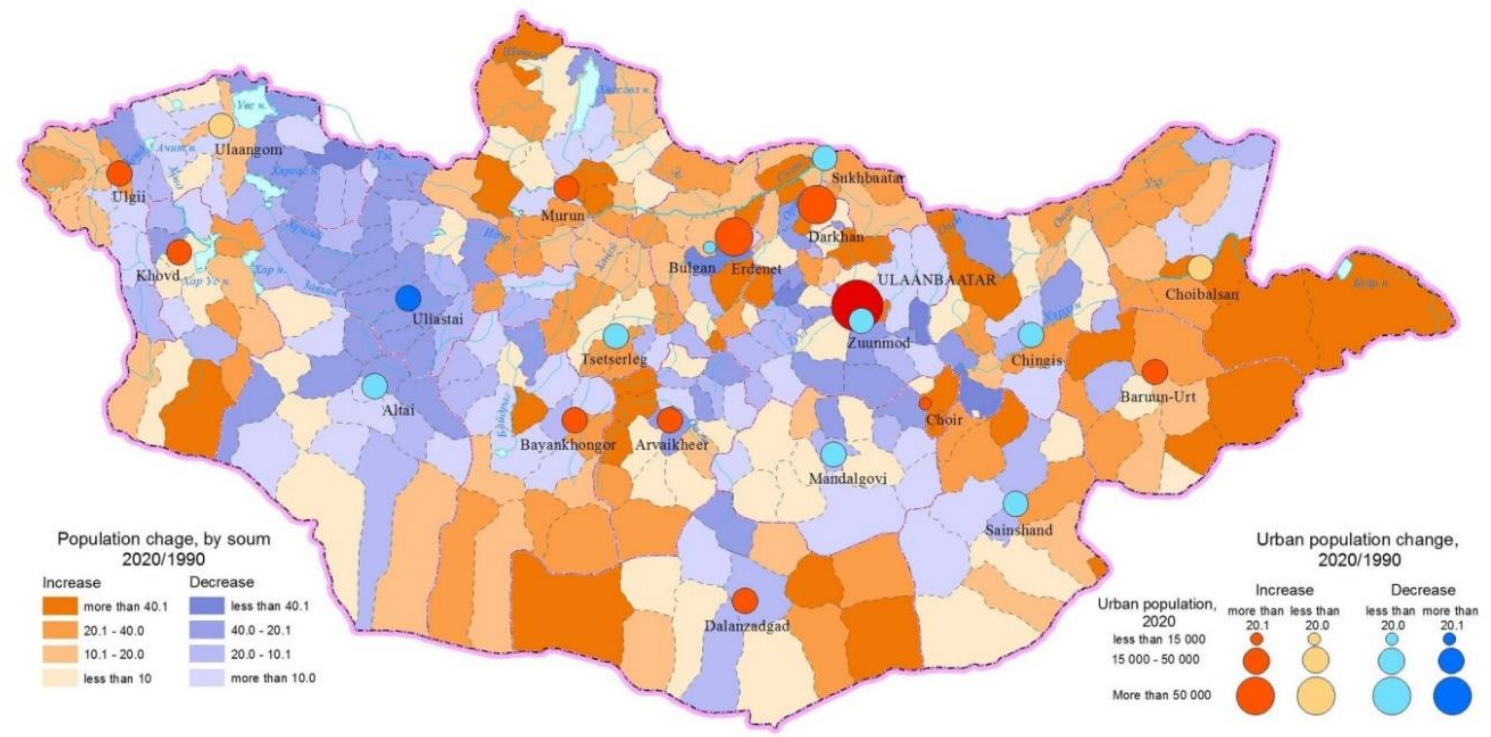

Figure 5. Population changes 1990-2020

Data source: National Statistical Year Book, 1990-2020, www.1212mn

\section{DISCUSSION}

Primary data on migration and urbanization as well as field survey results show that migration to Ulaanbaatar and in Bulgan, Erdenet, Darkhan, and Khuvsgul aimags intensified beginning in the 1990s. During Mongolia's transition to a market economy in 1990-2000, there was an increase in migration from rural to urban areas, mainly due to unemployment, job search, livelihood improvement, and vocational training.

The herders' main reasons for moving to urban areas between 2001 and 2010 was the worsening weather, including drought and dzud (winter freezes) in every year. Severe natural conditions, led to migration. Survey participants concluded that the drought and dzud that have occurred for several years in a row have resulted in significant livestock losses and local poverty.

Migration intensified to the Central Region and Ulaanbaatar, doubling between 2011 and 2020. The Central and Khangai regions are the gateways to Ulaanbaatar. As a result of migration flows to the Central and Khangai regions, where the mining industry is developed, to Umnugovi and Dornogovi aimags, there is a slight decrease in the flow of people to Ulaanbaatar.

Further effects on migration problems in Mongolia include administrative layouts. This includes soums within reach of the aimag center, or rural areas that are attracted to the aimag center. These soums are responsible for supplying the aimag center with agricultural products. Soum centers include soums that have lost their service to the aimag center and are only administratively responsible for serving herders. These include soums located on paved roads.

In addition to agriculture, the people of these soums are engaged in production and services and are obliged to serve road passengers. The rural population is responsible for providing agricultural products to the passenger service area. Herders also have other sources of income, such as introducing pastoralism to tourists, and selling their dairy livestock products. These soum centers will continue to grow.

The northern part of Mongolia, where agriculture industry is highly developed, is a relatively densely populated region. The population of these soums provides Mongolia with agricultural products, and many people also engage in intensive animal husbandry (cattle, pigs, bees) in order to conserve agricultural residues and wastes. Soum centers in these areas were better planned and developed than other soum centers, because they were established under the previous government. Due to the large population, there are many types of service responsibilities. In recent years, their migration has declined and the population has remained stable.

As to the development of the mining sector, people from soums have been migrating in large numbers in recent years. Herders are migrating and moving into mining work. However, while jobs are being created and settlements are being established, 
they are based solely on mining due to a lack of clear policies and planning. These settlements need to be supported and expanded in use by the government. This includes low-density soums with evenly distributed populations. The rural population there is engaged in traditional pastoralism, and the soum center serves as an administrative and service center for herders.

\section{CONCLUSIONS}

Internal migration has increased dramatically over the last 30 years in Mongolia, and continues to depend on many factors. Ultimately it depends on differences in internal economic development in Mongolia.

Field survey results show that migration in the future is likely to continue, particularly into mining and intermediary cities, and especially among young people moving to into cities. Most respondents said that migration will continue to increase. This is due to the lack of jobs in rural areas, living standards, limited market opportunities, and large differences in wealth compared to large cities.

As the population grows, in urban areas, the demand for basic necessities such as food, shelter, health, and education will continue to increase. As a result, the share of urban population in the total population is increasing.

In addition, Mongolia is experiencing spatial differences in population settlement as a result of socio-economic, industrial, service, ecological and cultural developments. Especially in the northern part of the central region of Mongolia, infrastructure development and natural conditions have led to a population which is more is densely populated from other areas. This creates a development trend of both population low-density homogeneity and concentration across the territory.

\section{REFERENCES}

[1] National Statistical Office of Mongolia (NSOM). Statistical Year Book 2017, Ulaanbaatar National Statistical Office of Mongolia 2005, 2010, 2020.

[2] National Statistical Office of Mongolia (NSOM). Statistical Year Book 2001, Ulaanbaatar National Statistical Office of Mongolia 1990, 2000.

[3] Mongolian Statistical Information Service (MSIS 2018), Population Migration, by aimag and the capital Ulaanbaatar 2020,
http://www.1212.mn/tables.aspx?TBL_ID=DT_ NSO_0300_040V1

[4] Bolormaa. Ts. 2011, "From Sensitive situation to sustainable development: environment, human development", Human development report of Mongolia, Ulaanbaatar, 2011

[5] Bazargur D, 2010, "Pastoral Geography" Institute of Geography, Social Economic Geography Department, Mongolian Academy of Science

[6] Social Economic Department Report 2010, (SEDR 2010) Examination of Social Economic Condition of Mongolia, Report, Social Economic Geography Department, Institute of Geography, Mongolian Academy of Sciences.

[7] National Statistical Office of Mongolia (NSOM). 2016 "2015 Population and housing by census of Mongolia, national report" Ulaanbaatar https://1212.mn/BookLibraryDownload.ashx?url =2015_Population_and_housing_bycensus_of_Mongolia_en.pdf\&ln=En

[8] Tsedensodnom. Kh 2003 "Mongolian population and environment" Ulaanbaatar rensodnom. 2003

[9] Alaev E.B., 1983. Socio-economic geography: Conceptual and terminological dictionary. Thought. 